\title{
Anotasi Putusan Perkara Tata Usaha Negara \\ antara Kuat, cs. melawan Pemerintah DKi Jakarta \\ tentang Pembatalan Izin Pelaksanaan Reklamasi Pulau G \\ (No. 193/G/LH/2015/PTUN-JKT)
}

Oleh: Rayhan Dudayev ${ }^{1}$

\section{Pendahuluan}

Selasa, 31 Mei 2016 merupakan hari yang menandai kemenangan Nelayan Muara Angke terhadap gugatan yang mereka lakukan terhadap Izin Pelaksanaan Reklamasi Pulau G di Teluk Jakarta. Lima orang nelayan bersama dua organisasi lingkungan hidup, Wahana Lingkungan Hidup Indonesia (Walhi) dan Koalisi Rakyat untuk Keadilan Perikanan (KIARA) mengajukan gugatan terhadap SK Gubernur DKI Jakarta No. 2238 Tahun 2014 di Pengadilan Tata Usaha Negara (TUN) Jakarta. Pasca tujuh bulan berselang, ketua majelis hakim, Adhi Budhi Sulistyo yang merupakan hakim lingkungan, mengabulkan gugatan nelayan dan menyatakan batal atau tidak sah SK yang dikeluarkan gubernur tersebut.

Putusan ini jelas memberikan angin segar bagi para nelayan dan masyarakat lainnya yang telah berjuang dalam mempertahankan tempat tinggal dan lingkungan hidup mereka terhadap pembangunan di kawasan pesisir bernama reklamasi. Di lain sisi, ada beberapa pihak, putusan ini dinilai politis dan dapat menghambat

1 Rayhan Dudayev adalah peneliti Indonesian Center for Environmental Law (ICEL) dalam Divisi Maritim. Penulis lulus S1 dari Fakultas Hukum Universitas Indonesia program kekhususan Hukum dan Masyarakat pada tahun 2014. 
kepastian investasi di negara ini $^{2}$. Namun, sebelum masuk ke dalam asumsiasumsi tersebut, masyarakat luas perlu mengetahui pertimbangan-pertimbangan yang digunakan hakim untuk mengabulkan gugatan para nelayan. Ada beberapa poin mengapa hakim mengabulkan tuntutan penggugat, yaitu:

1. Mengabaikan Undang-Undang Nomor 27 Tahun 2007 tentang Pengelolaan Wilayah Pesisir dan Pulau Kecil serta Undang-Undang Nomor 1 Tahun 2014 tentang Perubahan atas UU Nomor 27 Tahun 2007.

2. Tidak adanya rencana zonasi kawasan sebagaimana diamanatkan Pasal 7 ayat 1 UU Nomor 27 Tahun 2007.

3. Proses penyusunan amdal (analisis mengenai dampak lingkungan) tidak partisipatif dan tidak melibatkan nelayan.

4. Menimbulkan kerusakan lingkungan dan berdampak kerugian bagi para penggugat (nelayan).

Penting untuk mengelaborasi poin-poin tersebut. Terutama, pertimbangan hakim bersertifikat lingkungan ini banyak mempertimbangkan aspek-aspek hukum lingkungan yang dapat menjadi preseden yang baik bagi hakim lain dalam menangani kasus lingkungan hidup. Secara keseluruhan, hakim mengabulkan gugatan penggugat karena pasal 53 ayat (2) huruf a Undang-Undang No. 5 Tahun 1986 unsurnya terpenuhi, bahwa objek gugatan yang dikeluarkan gubernur DKI Jakarta tidak sesuai dengan ketentuan peraturan perundang-undangan yang berlaku.

\section{Kasus Posisi}

Sebelum memulai pengelaborasian pertimbangan putusan hakim, perlu diketahui terlebih dahulu kasus posisi dari terjadinya permasalahan terhadap penerbitan izin pelaksanaan reklamsi tersebut. Objek gugatan yang digugat oleh nelayan tidak berdiri dengan sendirinya. Beberapa proses menarik terjadi pada

2 Detik.com, "Pengelola Pulau G: Putusan PTUN yang Menangkan Nelayan Ganggu Investasi." Sumber: http://news.detik.com/berita/3222283/pengelola-pulau-g-putusanptun-yang-menangkan-nelayan-ganggu-investasi diakses pada 11 Agustus 2016 
proses penerbitan objek sengketa dimulai dari penerbitan izin prinsip hingga masuknya gugatan terhadap objek sengketa. Rangkaian dan momen penting dalam proses itu yaitu:

1. SK tentang pelaksanaan izin reklamasi diawali dikeluarkannya persetujuan prinsip reklamasi No. 1291/-1.794.2 yang dikeluarkan oleh Gubernur Fauzi Bowo pada 21 September 2012.

2. Sosialisasi AMDAL mulai dilakukan PT. Muara Wisesa (tergugat intervensi) melalui dibuatnya surat No. 002/OGL/MWS-PM/ X/2012 tanggal 10 Oktober 2012 yang ditujukan kepada Lurah Kelurahan Pluit perihal Permohonan Sosialisasi Amdal.

3. Tergugat telah mengumumkan perihal studi AMDAL pada Koran Harian Terbit halaman 10 pada tanggal 17 Oktober 2012 dan di media cetak Indopos halaman 9 tanggal 17 Oktober 2012.

4. Kepala Badan Pengelola Lingkungan Hidup Daerah (BLHD) Daerah Khusus Ibukota (DKI) Jakarta telah menerbitkan surat No. 30/Andal/-1.774.151 tanggal 30 Juli 2013 Perihal Rekomendasi Andal RKL-RPL Reklamasi Pulau G.

5. Pemerintah Propinsi Daerah Khusus Ibukota Jakarta Dinas Pekerjaan Umum menerbitkan surat No. 33310/-1.797.1 tanggal 16 Oktober 2014 Perihal Izin Membangun Prasarana yang ditujukan kepada PT.Muara Wisesa Samudra.

6. PT. Nusantara Regas dengan PT.Muara Wisesa Samudera telah melakukan suatu kerjasama yang dituangkan Nota Kesepahaman Bersama tentang Kajian keselamatan Pipa Gas Bawa laut No. 00800/ NR/ D000/P/2014 tertanggal 3 Nopember 2014.

7. Kepala BLHD DKI Jakarta menerbitkan Surat Keputusan Nomor: 107 Tahun 2014 tanggal 7 Pebruari 2014 Tentang Kelayakan Lingkungan Hidup Rencana Kegiatan Reklamasi Pulau G dan Surat Keputusan Nomor: 108 Tahun 2014 tanggal 7 Pebruari 2014 Tentang Izin Lingkungan Kegiatan Rencana Reklamasi Pulau G dengan waktu yang bersamaan.

8. Tergugat menerbitkan Keputusan Gubenur Propinsi Daerah Khusus Ibukota Jakarta Nomor: 2238 Tahun 2014 tertanggal 23 Desember 2014 tanggal tentang 
Izin Pelaksaaan Reklamasi Pulau G kepada PT. Muara Wisesa Samudra (Vide Bukti P-1, Bukti T- 1, dan T.II Intervensi-1)

9. Tergugat melakukan publikasi objek sengketa sejak Bulan Januari 2015 di website ( $\underline{\text { www.jakarta.go.id)}}$. Para penggugat di dalam dalilnya baru mendapatkan SK Keputusan Obyek pada tanggal 18 Juni 2015.

10. Pada tanggal 23 Maret 2015 Jakarta Monitoring Network (JMN) mengajukan gugatan di PTUN dengan objek sengketa yang sama yaitu SK No. 2238 Tahun 2014 dan pengadilan mengeluarkan penetapan Nomor 61/G/2015/PTUN-JKT.

11. Pada 22 April 2015, terdapat pernyataan dari salah satu anggota Walhi yang bernama Putra yang mengatakan akan melakukan gugatan terhadap SK izin pelasakanaan reklamasi Pulau G.

12. Perkara atas nama penggugat JMN dibacakan di muka umum dan diliput media nasional pada tanggal 12 Mei 2015.

13. Pada 29 Mei 2016 terdapat pemberitaan dari www.aktual.com yang memberitakan adanya kunjungan proyek reklamasi Pulau G oleh beberapa organisasi seperti Walhi Jakarta, LBH Jakarta, PBHI, YLBHI, dan ICEL.

14. Pada Bulan Mei 2016, JMN mencabut gugatan No. 61/G/2015/PTUN-JKT.

15. KIARA melakukan Permohonan Informasi sesuai dengan UU No. 14 Tahun 2008 tentang Keterbukaan Informasi Publik untuk meminta SK Gubernur DKI Jakarta No. 2238 Tahun 2014 pada tanggal 13 Mei 2016 dan menyerahkan surat keberatan informasi pada 3 Juni 2015 karena tidak mendapatkan tanggapan.

16. Pada tanggal 15 September 2015 para penggugat yang terdiri dari nelayan Muara Angke, Kuat, Gobang, Saefudin, Tri Sutrisno, dan Mohammad Tahir yang kemudian disebut penggugat I sampai $\mathrm{V}$ bersama organisasi lingkungan hidup Wahana Lingkungan Hidup Indonesia (WALHI) dan Koalisi Rakyat untuk Keadilan Perikanan (KIARA) yang disebut penggugat VI dan VII memasukan gugatan ke pengadilan negeri tata usaha negara (TUN). 


\section{Pertimbangan Putusan Hakim}

\section{A. Kedudukan Hukum Para Penggugat}

Dalam gugatan SK Izin Pelaksanaan Reklamasi Pulau G, terdapat penggugat dari perseorangan yang merupakan nelayan dan juga organisasi lingkungan hidup yang terdiri dari Walhi dan KIARA. Di dalam eksepsinya, Tergugat dan Tergugat Intervensi menyatakan bahwa seluruh penggugat tidak mempunyai kepentingan terhadap objek sengketa dan tidak memenuhi unsur pasal untuk menjadi wakil lingkungan hidup. Namun, hakim berpendapat lain. Hakim menerima standing para pihak terkecuali salah satu organisaisi.

\section{a. Nelayan Muara Angke}

Dalam gugatan SK Izin Pelaksanaan Reklamasi No. 2238 Tahun 2014, terdapat gugatan dari masyarakat (orang perorangan) dan organisasi lingkungan hidup. Dalam hal ini, masyarakat dari Muara Angke, Kuat, Gobang, Saefudin, Tri Sutrisno, dan Mohammad Tahir yang kemudian disebut penggugat I sampai $\mathrm{V}$ mengajukan gugatan, menuntut pencabutan izin tersebut. Hakim berpendapat gugatan yang diajukan oleh para nelayan tidak kabur dan para nelayan mempunyai standing untuk melakukan gugatan tersebut. Pertama, hakim berpendapat terdapat hubungan kausalitas secara langsung (causal verband) antara objek sengketa dengan para Penggugat (Penggugat I, II, III, IV, dan V). Selain itu, kerugian dalam kaitannya dengan lingkungan hidup tidak bisa hanya diukur dari kecilnya kerugian materiil saja, melainkan jika berpotensi menimbulkan akibat hukum khususnya bagi masyarakat Nelayan Muara Angke.

Dalam hal ini, hakim berpendapat, para nelayan yang sudah mulai terhambat akses keluar masuk ke laut merupakan unsur potensial kerugian. Dalam pertimbangan ini, hakim merujuk pada dasar hukum Pasal 87 UU No. 30 Tahun 2014 Tentang Administrasi Pemerintahan yang menyatakan Keputusan yang berpotensi menimbulkan akibat hukum, dikualifisir sebagai perluasan unsur konkrit, individual, final dari Keputusan Tata Usaha Negara. Untuk itu, hakim tidak menerima eksepsi Tergugat dan Tergugat II Intervensi 
tentang gugatan Para Penggugat yang menyatakan Penggugat I,II,III,IV, dan V sangat kabur dan tidak jelas.

\section{b. Hakim Menerima Hak Gugat Walhi}

Hakim menerima standing Walhi sebagai sebagai wakil lingkungan hidup. Menariknya, hakim menggunakan landasan filosofis tentang pentingnya keberadaan wakil untuk membela hak-hak yang dimimliki lingkungan hidup, sebagaimana dikemukakan Christoper Stone. Dalam putusannya, hakim mengutip pemikiran Stone bahwa semua benda-benda alam mempunyai hak yang dilindungi hukum (legal rights). Walaupun benda-benda ini bersifat inanimatif, ia tetap mempunyai hak. Supaya hak-hak ini dapat dijalankan maka kelompok-kelompok yang memiliki kepedulian terhadap lingkungan dapat ditunjuk sebagai wali dari lingkungan tersebut.

Berangkat dari pemikiran tersebut, hakim menyatakan konsep hak gugat konvensional berkembang seiring dengan perkembangan hukum terkait dengan public interest law. Artinya, Saat ini, kepentingan masyarakat luas atas pelanggaran-pelanggaran hak publik khususnya terkait dengan lingkungan hidup, perlindungan konsumen hak civil dan politik dapat diwakilkan oleh wali atau guardian. Seseorang atau sekelompok orang atau organisasi dapat bertindak sebagai Penggugat walaupun tidak memiliki kepentingan hukum secara langsung. Hak gugat tidak hanya dilandasi prinsip konvensional point $d^{\prime}$ interest point $d^{\prime}$ interest ${ }^{3}$ saja atau atau kepentingan materiil berupa kerugian yang dialami langsung (injury in fact).

Selain itu, hakim berpendapat hukum positif Indonesia telah megakui adanya gugatan melalui organisasi lingkungan hidup. Hak gugat lingkungan hidup diatur dalam UU No. 32 tahun 2009 tentang Perlindungan dan Pengelolaan lingkungan hidup (UUPPLH) yang diatur dalam pasal 92 yang rumusannya adalah sebagai berikut :

(1) Dalam rangka pelaksanaan tangung jawab Perlindungan dan Pengelolaan lingkungan hidup, organisasi lingkungan hidup berhak mengajukan gugatan untuk kepentingan pelestarian lingkungan hidup ;

3 Tiada gugatan tanpa kepentingan hukum 
(2) Hak mengajukan gugatan terbatas pada tuntutan untuk melakukan tindakan tertentu tanpa adanya tuntutan ganti rugi, kecuali biaya atau pengeluaran riil ;

(3) Organisasi lingkungan hidup dapat mengajukan gugatan apabila memenuhi persyaratan:

a. Berbentuk Badan Hukum;

b. menegaskan didalam anggaran dasarnya bahwa organisasi tersebut didirikan untuk kepentingan pelestarian fungsi lingkungan hidup, dan

c. telah melaksanakan kegiatan nyata sesuai dengan anggaran dasarnya paling singkat 2 (dua) tahun;

\section{c. KIARA dikeluarkan karena tidak memenuhi unsur pasal 92 UUPPLH}

Menurut hakim, KIARA tidak memenuhi semua ketentuan pasal 92. KIARA dianggap tidak memenuhi syarat huruf (a) dari Pasal 92 ayat (3) Undang-Undang Lingkugan Hidup sehingga Perkumpulan KIARA / Penggugat VI tidak mempunyai hak gugat (Legal standing ) oleh karenannya Perkumpulan Koalisi Rakyat untuk Keadilan Perikanan (KIARA) harus dikeluarkan sebagai pihak dalam sengketa ini. Pertimbangan hakim yaitu:

1. Perkumpulan Indonesia yang sudah berbadan hukum harus didaftarkan dalam suatu register khusus pada Kepaniteraan Pengadilan Negeri dan diumumkan dalam Berita Negara (pasal 18-19 Stb. 1942-13 jo 14). Oleh karenanya untuk sebuah perkumpulan menjadi berbadan hukum, harus mendapatkan pengesahan dari pejabat yang berwenang terlebih dahulu. Pada saat ini, pengesahan perkumpulan berbadan hukum diberikan oleh Menteri Hukum dan Hak Asasi Manusia Republik Indonesia.

2. KIARA mengajukan gugatan sengketa Tata Usaha Negara dalam konteks sengketa lingkungan hidup belum mendapat persetujuan bahkan pengesahan dari Direktoral Jendral Administrasi Hukum Umum Kementerian Hukum dan Hak Asasi Manusia Republik Indonesia

Namun, KIARA dianggap mempunyai anggaran dasar yang bertujuan untuk perlindungan lingkungan hidup, terutama ekosistem laut. Selain itu, berdasarkan bukti-bukti yang diajukan penggugat, KIARA telah terbukti 
melakukan kegiatan terkait perlindungan lingkungan hidup seperti penerbitan buku terkait nelayan, pengujian UU Minerba, Menguji UU Perikanan, dll selama dua tahun. Namun dalam KIARA sebagai penggugat, hakim tidak menggunakan dasar huku maupun teori dalam mengeluarkan KIARA sebagai pihak.

\section{B. Pertimbangan terkait jangka waktu}

Hakim menganggap gugatan para penggugat masih masuk dalam tenggat waktu dan dua penggugat gugatannya telah melewati batas waktu sebagaimana yang diatur di dalam Pasal 55 UU No. 5 Tahu 1986 dengan beberapa argumentasi yaitu:

1. Gugatan yang diajukan oleh Jakarta Monitoring Network (JMN) pada Bulan Mei tidak membuat para penggugat seperti para nelayan mengetahui objek sengketa secara serta merta. Selain itu, hakim berpendapat bahwa Penetapan No. 61/G/2015/PTUN-JKT tidak mempunyai kekuatan mengikat daya berlakunya dengan perkara yang diajukan oleh nelayan beserta WALHI dan KIARA dengan No. 193/G/LH/2015/PTUN-JKT. Menurut majelis hakim, gugatan yang diajukan JMN masih dalam tahap awal yaitu tahap pemeriksaan persiapan yang dibacakan dalam persidangan yang terbuka untuk umum. Penetapan pencabutan atas gugatan JMN tersebut hanya mempunyai kekuatan kepada subyek hukum yang melakukan pencabutan gugatan tersebut. Selanjutnya, yang menarik yaitu pendapat hakim yang mengatakan bahwa penetapan pencabutan suatu gugatan TUN tidak berlaku asas orga omnes.

2. Alasan hakim mengeluarkan Walhi sebagai penggugat dikarenakan keterangan anggota WALHI yang bernama Putra pada Bulan Mei 2015 yang mengatakan akan melakukan gugatan. Selain itu, WALHI dianggap mengetahui objek sengketa karena telah melakukan kunjungan lapangan ke pelaksanaan reklamasi Pulau G pada tanggal 29 Mei 2015. Hakim menganggap sejak tanggal 29 Mei 2015 WALHI telah mengetahui objek sengketa, sedangkan gugatan yang diajukan pada 15 Septermber 2015 sudah memakan waktu 142 hari atau melebih 90 hari sebagaimana yang tercantum dalam pasal 55 UU No. 5 Tahunn 1986. VII Berdasarkan hal tersebut, hakim mengeluarkan Walhi 
sebagai Penggugat. Sedangkan KIARA dikeluarkan sebagai penggugat karena dianggap telah mengetahui informasi melalui permohonan informasi sejak 3 Juni 2015 yang artinya gugatan yang diajukan sudah memasuki hari ke 104 atau lebih dari 90 hari.

3. Mengenai pertimbangan penggugat I-V, para nelayan, hakim mempertimbangkan para penggugat tersebut belum melewati 90 hari gugatannya. Adapun alasan-alasan yang digunakan hakim yaitu tidak ada satu pun nama penggugat, Gubang, Muhammad Tahir, Nur Saepudin, Tri Sutrisno, dan Kuat termuat di dalam media cetak. Hakim menganggap, para penggugat belum mengetahui obyek sengketa. Selain itu, Hakim mempetimbangkan pemberitaan media yang mengutip pernyataan Muhammad Isnur yang menyatakan bahwa nelayan baru mengetahui objek gugatan melalui bantuan LBH Jakarta dengan proses pengajuan keterbukaan informasi publik. Berdasarkan ketentuan tersebut, Isnur menyatakan nelayan baru mendapatkan informasi sekitar Bulan Maret - April. Para penggugat dianggap mengetahui objek sengketa setelah mendapatkan informasi dair KIARA pada tanggal 18 Juni 2015 melalui jawaban permohonan informasi yang diajukan KIARA.

\section{Pokok Perkara}

\section{A. Pertimbangan AMDAL yang tidak partisipatif}

Hakim memutuskan bahwa izin lingkungan yang dimiliki PT. Muara Wisesa cacat formil karena dianggap proses penyusunan AMDAL tidak transparan dan partisipatif. Hakim mengawali pertimbangannya dengan penjelasan Hukum Administrasi Lingkungan mempunyai peran yang sangat signifikan di dalam sistem perlindungan dan pengelolaan lingkungan hidup. Hukum Administrasi Lingkungan berfungsi sebagai sarana yuridis yang sifatnya pencegahan (preventif) terhadap kerusakan lingkungan. Instrumen pencegahan ini adalah menjadi substansi dari hukum administrasi lingkungan didalam menciptakan pembangunan berkelanjutan (sustainable development) dibidang lingkungan hidup 
Menurut hakim, hukum administrasi lingkungan dimaknai dengan pelaksanaan sistem perizinan lingkungan dalam pengelolaan lingkungan hidup dan adanya prosedur administrasi yang berupa AMDAL. Kedua instrumen tersebut dianggap kedua mempunyai kaitan satu sama lainnya, serta pentingnya penerapan prinsip-prinsip hukum lingkungan seperti pelestarian lingkungan, prinsip perlindungan, dan prinsip pencegahan pencemaran lingkungan hidup. Dari poin tersebut, hakim berangkat untuk mengargumentasikan pertimbangannya terkait dengan pentingnya mematuhi syarat formil yang diatur dalam UU No. 32 Tahun 2009 untuk memastikan terlaksananya prinsip pembangunan berkelanjutan. Dalam poin ini, hakim meyakin, hukum administrasi lingkungan dapat mencegah pencemaran dan pengrusakan lingkungan hidup.

Pada proses penyusunan AMDAL, hakim menganggap Tergugat terbukti telah melanggar Pasal 30 ayat (1) UUPPLH dan prosedur formal yaitu keterlibatan masyarakat terkait Penetapan Wakil Masyarakat dalam penyusunan dokumen Amdal. Secara substantif keterlibatan masyarakat sangat mempengaruhi proses pelingkupan dalam penyusunan dokumen Amdal. Adapun yang menjadi dasar pertimbangan hakim terkait penyusunal AMDAL yang tidak parsipatif yaitu:

1. Walaupun PT. Muara Wisesa telah melakukan pengumuman terhadap aktivitas penyusunan AMDAL melalui media cetak Indopos pada halaman 9 tanggal 17 Oktober 2012 dan sosialisasi jugaa tanggal 17 Oktober 2012, hakim tidak menganggap proses tersebut cukup partisipatif dan transparan. Hakim memandang, sosialisasi secara intens harus dilakukan, terutama terhadap Warga Muara Angke, warga yang terkena dampak. Masyarakat Muara Angke dianggap belum sepakat terhadap proses pembangunan. Ihwal tersebut diperkuat juga dengan keterangan saksi ahli yang diajukan oleh Pihak Tergugat Intervensi II, Hesti D.W. Nawangsidi yang menyatakan masyarakat tidak puas dengan rencana pembangunan proyek reklamasi.

2. Berdasarkan Notulen Pembahasan Tim Teknis Penilai AMDAL Daerah Provinsi DKI Jakarta, di lampiran undangan Pembahasan Dukumen Andal oleh Tim Teknis Propinsi Daerah Khusus Ibukota Jakarta tidak melibatkan dan mengikutsertakan masyarakat yang terkena dampak, pemerhati lingkungan hidup dan atau yang terpengaruh atas segala bentuk keputusan dalam proses AMDAL. 
3. Pemrakarasa juga dianggap melanggar tata cara pengikutsertaan masyarakat dalam proses Amdal secara teknis diatur pada Peraturan Menteri Negara Lingkungan Hidup No. 17 Tahun 2012 Tentang Pedoman Keterlibatan Masyarakat. Dalam dokumen AMDAL, tidak terdapat pembahasan tentang penetapan wakil masyarakat baik dalam bentuk persetujuan ataupun surat kuasa yang ditanda tangani oleh yang diwakili berupa penetapan wakil masyarakat sebagaimana ditentukan pada Peraturan Menteri Negara Lingkungan Hidup No. 17 Tahun 2012.

4. Ragam partisipan keterlibatan masyarakat harus diperhatikan sehingga dalam tahap pemberian saran, pendapat dan tanggapan secara substantif benar-benar mewakili aspirasi masyarakat.

5. Hakim menganggap penerbitan izin lingkungan dari izin pelaksanaan Pulau G tidak sah karena tidak sesuai dengan prosedur pasal 39 UU 32 Tahun 2009. Berdasarkan bukti-bukti yang diajukan baik dari pihak Tergugat maupun Tergugat II tidak ada satu buktipun yang menunjukan bahwa tergugat telah melakukan pengumuman sebagaimana yang ditentukan dalam UndangUndang No. 32 tahun 2009 tentang Perlindungan dan pengelolaan lingkungan hidup pasal 39 dan Peraturan Pemerintah Nomor 27 Tahun 2012 Tentang Izin Lingkungan pasal 44.

\section{B. Objek Sengketa tidak sesuai peraturan perundang-undangan}

Penerbitan Izin Pelakssanaan reklamasi tidak sesuai dengan ketentuan hukum. Penerbitan objek sengketa oleh Pihak Tergugat cacat hukum karena selain terbukti penerbitan objek sengketa in litis telah bertentangan dengan ketentuan peraturan perundang-undangan, juga terbukti melanggar azas-azas Umum Pemerintahan yang Baik (AAUPB) seperti azas kecermatan dan ketelitian. Beberapa poin yang melandasi pernyataan hakim yaitu:

1. Izin Prinsip Reklamasi dan Perpanjangan Izin Prinsip Reklamasi tidak mencantumkan secara lengkap dasar hukum penerbitan objek sengketa. Di dalam objek sengketa tidak dicantumkannya Undang-Undang Nomor 27 Tahun 2007 sebagaimana diubah dengan Undang-Undang Nomor 1 Tahun 
2014 di dalam konsideran. Hakim mengacu pada ketentuan Pasal 5 ayat (1) Undang Undang Nomor 30 Tahun 2014 Tentang Administrasi Pemerintahan "Setiap keputusan harus diberi alasan pertimbangan yuridis, soiologis dan filosofis yang menjadi dasar penetapan Keputusan" selanjutnya dalam ketentuan Pasal 56 ayat (1) "Keputusan yang tidak memenuhi persyaratan sebagaimana dimaksud dalam Pasal 52 ayat (1) huruf a merupakan keputusan yang tidak sah."

2. Pemda DKI Jakarta belum membentuk Perda Rencana Zonasi Wilayah Pesisir dan Pulau Pulau Kecil (RZWP-3-K). Perda tersebut merupakan mandat dari Pasal 7, Pasal 9 dan Pasal 10 Undang Undang No. 27 Tahun 2007 sebagaimana telah diubah dengan Undang Undang No. 1 Tahun 2014. tentang WP3K. Pemerintah Daerah wajib menyusun Rencana Zonasi serta menetapkannya dengan Perda. Rencana Zonasi tersebut berfungsi sebagai alat kontrol untuk keseimbangan pemanfaatan, perlindungan pelestarian, dan kesejahteraan masyarakat sekaligus berfungsi memberikan kepastian dan perlindungan hukum dalam pemanfaatan perairan pesisir.

\section{Objek putusan dianggap hakim mendesak untuk dilakukan penundaan dilihat dari dampak ekologis dan sosial}

Dalam perkara ini, hakim berpendapat apabila objek sengketa tetap dilaksanakan, kerusakan yang akan ditimbulkan akan lebih besar dibandingkan manfaat yang akan dirasakan masyarakat. Hakim mengabulkan tuntutan penundaan pelaksanaan KTUN karena tidak ada sangkut pautnya dengan kepentingan umum dalam rangka pembangunan sesuai Pasal 67 ayat (4) huruf a dan b UU No. 5 Tahun 1986 tentang PTUN. Hakim menganggap objek sengketa cukup mendesak untuk dihentikan berdasarkan keterangan dari Saksi Ahli yang dihadirkan Tergugat, Hesti Nawangsidi dan juga saksi ahli yang dihadirkan penggugat, Alan Karopitan, yaitu:

1. Banyak sekali dampak-dampak yang ditimbulkan oleh aktivitas reklamasi.

Dampak lingkungan hidup yang perlu dikaji dampaknya bisa bersifat fisik, biotik, sosial ekonomi dan juga terhadap infrastruktur. ${ }^{4}$

$4 \quad$ Keterangan ahli Hesti Nawangsidi di dalam persidangan 
2. Reklamasi akan menimbulkan pencemaran terhadap perairan laut. Kegiatan reklamasi akan mengubah lingkungan sekitarnya. Kegiatan-kegiatan seperti mengurug di perairan laut berpoteni menimbulkan butiran-butiran yang tersebar ke perairan disekitarnya.

3. Kemampuan natural flushing (kemampuan air laut untuk membersihkan dirinya) akan berkurang drastis dengan adanya reklamasi. Dengan bertambahnya flushing time atau waktu pencuciannya, sedimentasi akan meningkat dan menumpuk. Kandungan cemar di Teluk Jakarta semakin lama tertinggal dasar laut dan berakumulasi. ${ }^{5}$

4. Objek Gugatan tidak termasuk dalam definisi pembangunan untuk kepentingan umum sebagaimana diatur dalam Undang-Undang No. 2 Tahun 2012.

\section{Kewenangan Mengeluarkan Objek Sengketa ada di Tangan Gubernur}

Walaupun hakim mengabulkan tuntutan para penggugat, namun hakim tidak menerima dalil para penggugat yang menyatakan bahwa kewenangan mengeluarkan izin pelaksanaan reklamasi Pulau G ada di tangan gubernur. Dikarenakan tidak diatur secara jelasnya kewenangan mengeluarkan izin di dalam izin pelaksanaan reklamasi di dalam Undang-Undang, hakim mengacu kepada peraturan yang lebih rendah, yaitu Perpres No. 122 Tahun 2012 tentang Pelaksanaan Reklamasi di WP3K dan Permen KP No. 28 Tahun 2014. Dalam hal ini, hakim berpendapat bahwa walaupun Teluk Jakarta merupakan Kawasan Strategis Nasional (KSN), tetapi kewenangan mengeluarkan izin pelaksanaan reklamasi tetap ada di gubernur. Alasan utamanya yaitu di dalam Perpres 122 Tahun 2012 hanya mengatakan bahwa kewenangan mengeluakan izin oleh pemerintah pusat hanya di Kawasan Strategis Nasional Tertentu (KSNT) bukan KSN.

Namun, putusan hakim ini sebenarnnya menimbulkan dampak laten terhadap pelaksanaan reklamasi yang izinnya dapat dikeluarkan dengan mudah oleh pemerintah daerah. Walaupun hakim mempertimbangkan untuk menunda objek sengketa karena berpotensi menimbulkan dampak buruk terhadap

5 Putusan Pengadilan Negeri Jakarta No. 193/G/LH/2015/PTUN-JKT, hal. 165. 
lingkungan hidup, hakim tidak mengindahkan bunyi pasal 105 PP No. 26 Tahun 2008 tentang Kawasan Strategis Nasional. Di dalam aturan tersebut, pembangunan yang berdampak besar terhadap lingkungan hidup, maka kewenangannya ada di pemerintah pusat. Seharusnya, dengan mengacu pada keterangan-keterangan ahli, terutama yang terkait dengan lingkungan laut, reklamasi dapat dikatakan merupakan pembangunan yang dapat menimbulkan dampak luas terhadap lingkungan hidup.

\section{Simpulan}

Di dalam Putusan Pengadilan Negeri Jakarta dengan perkara No. 193/G/ LH/2015/PTUN-JKT, terdapat beberapa poin yang perlu digarisbwahi yang penting untuk masuk dalam kesimpulan, yaitu:

1. Hakim tidak menerima standing KIARA karena dianggap tidak punya standing karena belum terdaftar dalam Kemenkumham sehingga tidak memenuhi unsur Pasal 92 UU 32 Tahun 2009 yang mengisyarakatkan organisasi lingkungan hidup harus berbentuk badan hukum.

2. Gugatan Walhi dianggap telah melewati jangka waktu yang diatur dalam PerUUan karena Walhi dianggap telah mengeluarkan pernyataan terkait objek sengketa jauh sebelum melakukan gugatan.

3. Hakim berpendapat para nelayan sebagai penggugat mempunyai hubungan kausalitas secara langsung (causal verband), antara objek sengketa dengan para Penggugat.

4. Seseorang atau sekelompok orang atau organisasi dapat bertindak sebagai Penggugat walaupun tidak memiliki kepentingan hukum secara langsung seiring adanya konsep guradian berdasarkan pemikiran Christoper Stone. Hak gugat tidak hanya dilandasi prinsip konvensional point d'interest point d'interest saja atau atau kepentingan materiil berupa kerugian yang dialami langsung (injury in fact).

5. Hakim memutuskan bahwa izin lingkungan yang dimiliki PT. Muara Wisesa cacat formil karena dianggap proses penyusunan AMDAL tidak transparan 
dan partisipatif.

6. Penerbitan Izin Pelakssanaan reklamasi tidak sesuai dengan ketentuan hukum dikarenakan tidak didahului RZWP3K sebagai dasar perencanaan ruang di WP3K dan tidak memasukan UUWP3K di dalam konsideran objek sengketa.

7. Hakim mengabulkan tuntutan penundaan dikarenakan kerusakan yang akan ditimbulkan akan lebih besar dibandingkan manfaat yang akan dirasakan masyarakat.

8. Hakim memutuskan kewenangan mengeluarkan Izin Pelaksanaan Reklamasi Pulau G ada di tangan gubernur tanpa mempertimbangkan pasal 105 PP No. 26 Tahun 2008 yang kaitannya dengan kewenangan izin yang dikeluarkan pemerintah pusat terhadap kegiatan yang berdampak besar terhadap lingkungan hidup. 
